\title{
Sustainable Development of Krasnoyarsk Krai: New Estimates
}

\author{
Anton I. Pyzhev*, Ekaterina A. Syrtsova, \\ Yulia I. Pyzheva and Evgeniya V. Zander* \\ Siberian Federal University \\ 79 Svobodny, Krasnoyarsk, 660041, Russia
}

Received 06.09.2015, received in revised form 26.09.2015, accepted 10.10.2015

In this paper we introduce the updated estimates of Genuine Savings and Green GRP and give an overview of complex estimation of sustainable development level of Krasnoyarsk Krai. For indicators specifying environmental damage we considered depletion of natural resources and the damage caused by emission of pollutants into the environment. Dynamics of both indicators has been found negative: the tendency of Krasnoyarsk Krai development is still unsustainable. This trend is kept since the mid of 2000s, when the previous estimation of the Genuine Savings and Green GRP was made. The above-stated results correspond to the estimation of Genuine Progress Indicator in 2005-2011 accurate within the accounting of social sphere indicators of sustainable development.

Keywords: Sustainable Development, Genuine Savings, Ecologically Adjusted Gross Regional Product, Genuine Progress Indicator, Regional Economics.

The publication was prepared within the framework of the project no. 14-12-24003 sup-ported by the Russian Foundation for Humanities and Krasnoyarsk Krai Foundation for Support of Scientific and Technical Activity.

DOI: 10.17516/1997-1370-2015-8-11-2590-2595.

Research area: economics.

\section{Introduction}

During the last decades a new vision to the assessment of development level of countries and their regions arose. The new approach suppose that macroeconomic indicators, such as Gross Domestic Product, could not be the only measures of real progress of nations and separate territories. The concept of sustainable development introduced in late 1980 s has sufficiently enriched the basis of measuring of development level of nations by taking into account ecological and social factors (Costanza et al., 1997, 2004, 2014).

The problem of sustainable development is of a great importance for Russia, mainly on regional scale, because of spatial inequality of the territory of Russia. Several studies on the assessment of interregional inequality of Russian regions towards the accomplishment of sustainable development goals were made (Bobylev et al., 2013, 2015; Glazyrina et al.,

(c) Siberian Federal University. All rights reserved

* Corresponding author E-mail address: pyanist@ya.ru 
2010; Zabelina and Klevakina, 2011; Klevakina and Zabelina, 2012). The situation tends to change during last years, because the successful model of economic development based on high prices of oil and gas, which form half of the Russian budget, seems to be exhausted, so one needs to find some new sources of the economic growth. We urge that before making of a well-proven economic policy for the next decades, it is critically needed to create a good instrument of assessment of genuine progress of all components of human well being in Russia. In this paper we'll make the first step and propose a technique for such assessment on the regional scale that is based on the GPI methodology. Our study object is Krasnoyarsk Krai, a huge region in the center of Russia with highly developed industry of natural resources. Earlier we performed the assessment of the Genuine Savings indicator for Krasnoyarsk Krai in the second half of 2000s (Zander et al., 2010a, 2010b).

The focus of our previous studies was made on evaluation of sustainable development level of Krasnoyarsk Krai, an important industrial center of Siberia. The estimates of Genuine Savings indicator in 2004-2008 and Genuine Progress Indicator in 2005-2011 have been done (Zander et al., 2010a, 2010b; Pyzhev et al., 2014, 2015). In this paper we introduce the updated estimates of Genuine Savings and give an overview of complex estimation of sustainable development level of Krasnoyarsk Krai.

\section{Data and Methods}

The methodology of genuine saving assessment is based upon a widely known approach of World Bank (Manual..., 2002). The Genuine Savings indicator is deducted from Gross National Saving according to the following formula:

$$
\mathrm{NAS}=\left(\mathrm{GNS}-\mathrm{D}_{\mathrm{h}}+\mathrm{CSE}-\Sigma \mathrm{R}_{\mathrm{n}, \mathrm{i}}-\mathrm{CD}\right) / \mathrm{GNI},
$$

where GNS - Gross National Savings, $D_{h}$ - fixed asset depreciation, CSE - current spendings on education (human capital investments), $\Sigma \mathrm{R}_{\mathrm{n}, \mathrm{i}}$ natural resource rent (cost of natural resource depletion), $\mathrm{CD}$ - cost of damage caused by $\mathrm{CO}_{2}$ emissions, GNI - Gross National Income.

In previous studies was stated that there is no difficulty to assess the variables provided by the System of National Accounts, so the GNS, $D_{h}$ and GNI could be easily calculated. The main problem of Genuine Savings estimation arises when trying to evaluate the variables connected with nature resource use and the air pollution, since lack of consistent and trustworthy data on some components of the mentioned indicators. It was possible to collect the necessary data for 2013, so we give the new estimate of the Genuine Savings of Krasnoyarsk Krai for this year.

Krasnoyarsk Krai extracts the following types of natural resources: non-renewable nickel, copper, gold, oil, gas, coal; renewable forest resources.

According to the World Bank recommendations to evaluate the rent on nickel (Ni), copper $(\mathrm{Cu})$ and gold $(\mathrm{Au})$ from the cost of their production at world prices it is required to deduct the total cost of their production. One should note, that all the said resources are released products of metallurgical production and are produced from respective ores: coppernickel, gold bearing (oxidized and sulphide). The released metals referred to above whose world price is recommended for use by the WB, accordingly, comprise a substantial share of added value not related to depletion of natural capital, thus, the depletion estimate shall be considerably overestimated. According to the authors to evaluate the subsoil depletion damage is more correct by the primary cost of extraction of extracted ores, not by the primary cost of 
metal production, i. e. to take into account related immediately to the extraction process, and, as mentioned above, without regard to the world prices. Implementation of the author's approach to depletion of natural resources gives rise to the problem to define the cost of extracted coppernickel ore from which later metals shall be extracted: nickel and copper. Nickel and copper are known to be extracted from the same volume of copper-nickel ore. Therefore, the cost of ore produced separately for the copper and for nickel should be averaged.

It is important to evaluate the share of cost of ore mining in the net cost of released metal. Company reports comprise data on the volume of ore removed from a deposit and the output of produced metal. Since how much metal is produced from a specific ore type is not known, we use averaged indicators: total output of metal production and total ore production (not taking into account different content in the ore of the useful component - metal). The calculus yields average estimate of the share of the ore cost in the primary cost of the metal, then, multiplying it by the known primary cost of the metal have the cost of a ton of removed ore.

To measure the environmental pollution we use the prior simple approach. Cost of damage caused by $\mathrm{CO}_{2}$ emissions is estimated using the data on different kind of substances making damage to the air quality and ozone layer of the planet (solid substances, sulfur dioxide, nitrogen oxide, carbon oxide, hydrocarbons, volatile organic compounds). The Global Warming Potentials of each kind of substance is used to recalculate the damage volume into $\mathrm{CO}_{2}$-equivalents, which could be then easily converted into value of damage using the estimate of \$US 20 per metric ton of carbon dioxide emission.

The forest rent is determined taking into account the cost of afforestation. The net cost of forest logging has been assessed using the data of timber auctions (Pyzhev, 2015).

\section{Results and Discussion}

The results of estimation of Genuine Saving indicator of Krasnoyarsk Krai in 2013 are the following. The cost of damage caused by $\mathrm{CO}_{2}$ emissions was $18,926.9 \mathrm{mln}$ rubles. The resources of coal have been depleted for 29,984 mln rubles, oil-446,627.52 $\mathrm{mln}$ rubles, gas-35,635.4 $\mathrm{mln}$ rubles. The losses of mineral resources were less: gold-30,969.19 mln rubles, copper-33,081.94 mln rubles, nickel-45,377.35 mln rubles. The shares of different kinds of recourse in overall depletion are shown on Fig. 1.

One could see that the main damage for natural resource stocks was the result of Vankor oil deposit implementation in 2009.

Forest resources have been depleted only for $1,808.79 \mathrm{mln}$ rubles, which is considerably less than the losses of minerals.

The human capital investments were only $7.6 \%$ of the overall expenditures of regional budget-one of the least levels through the whole Siberia.

The damage caused by carbon dioxide emissions could be estimated as $1.5 \%$ of GRP.

In 2013 the Genuine Savings of Krasnoyarsk Krai were $-18.9 \%$, so the ecologically adjusted, or "Green" GRP was 1.019,2 bln rubles against $1.256,7$ of the basic one. Comparing with the results of our previous studies for the period of 2004-2008 (the GS value varied from $-20 \%$ to $22 \%$ ), it is evident that the previously revealed tendency of depletion of natural resource potential of the region is kept.

The results of our assessment of Krasnoyarsk Krai Genuine Progress Indicator showed that GPI was at least 30-35\% lower than GRP (Pyzhev et al., 2014). It was noted before that our estimation of GPI seems to be lower than its actual value, because some of important indicators were missing 


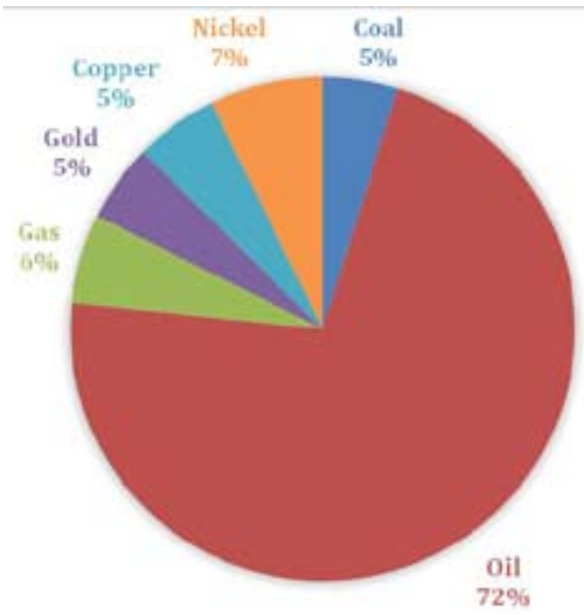

Fig. 1. Shares of different minerals in depletion of Krasnoyarsk Krai natural resources in 2013

or the data was not complete. Some estimates used for calculation were quite rough and need further justification. Major part of missing data covered the negatively impacting factors, so if they would have been accounted, the GPI will sufficiently decrease. Nevertheless, last years of scope (2010 and 2011) GRP is about $20-25 \%$ of GRP. Such a huge gap may be explained with a heavy ecological load of Krasnoyarsk Krai. The similar results were gained using the Genuine Savings instrument. It is obvious that the main component of GS and GPI of Krasnoyarsk Krai comprises the depletion of natural resources. The difference is in accounting arises because of social sphere indicators involved into assessment of GPI.

\section{Conclusion}

Thus, the study estimated Genuine Savings and Green GRP for Krasnoyarsk Krai in 2013 with account of its economic growth specifics. Environmental damage inflicted to the region by its intensive industrial exploitation has been estimated. For indicators specifying environmental damage we considered depletion of natural resources and the damage caused by emission of pollutants into the environment.
Dynamics of both indicators has been found negative: the tendency of Krasnoyarsk Krai development is still unsustainable. This trend is kept since the mid of $2000 \mathrm{~s}$, when the previous estimation of the Genuine Savings and Green GRP was made. The above-stated results correspond to the estimation of Genuine Progress Indicator in 2005-2011 accurate within the accounting of social sphere indicators of sustainable development.

The level of economic development and growth rates of the region made by the GRP value and its components tend to be overestimated due to disregard of environmental damage in this measure. On the whole from the viewpoint of the authors to restrain environmental impact of industry requires to develop approaches to environment use on the compensation basis. The question is that the environmental policy of a country (region, municipal entity) should provide for tools making possible to charge the cost of environmental damage to a specific economic entity, making it either change the production technology for more ecologically «clean» ones, or invest into environment-protection measures funds adequate to sustain the assimilation potential of the territory. 
There is a certain experience of to comparatively evaluate current state of developing methods for environmental and economic assessment of environment quality by international organizations and individual researchers, however, all of them are oriented environment of countries or regions and are unable to reflect effects of parametric variation specifying activities of industrial facilities.

\section{References}

Bobylev, S. N., Solovieva, S. V., \& Sitkina, K. S. (2013). Indikatory ustoichevogo razvitiya Ural'skogo regiona [Indicators of sustainable development of the Ural region]. Ekonomika Regiona [Economics of Region], 2 (34), 10-17.

Bobylev, S., Zubarevich N., Solovyeva S. (2015). Vyzovy Krizisa: kak izmeryat' ustoichivost' razvitiya? [Challenges of the Crisis: How to Measure Sustainable Development?]. Voprosy Ekonomiki, (1), 147-160.

Costanza, R., Kubiszewski, I., Giovannini, E., Lovins, H., McGlade, J., Pickett, K. E., et al. (2014). Development: Time to leave GDP behind. Nature, 505(7483), 283-285. doi:10.1038/505283a.

Costanza, R., Erickson, J., Fligger, K., Adams, A., Adams, C., Altschuler, B., et al. (2004). Estimates of the Genuine Progress Indicator (GPI) for Vermont, Chittenden County and Burlington, from 1950 to 2000. Ecological Economics, 51(1-2), 139-155.

Costanza, R., d'Arge, R., de Groot, R., Farber, S., Grasso, M., Hannon, B., et al. (1997). The value of the world's ecosystem services and natural capital. Nature, 387(6630), 253-260. doi:doi:10.1038/387253a0.

Glazyrina, I. P., Zabelina, I. A., \& Klevakina, E. A. (2010). Uroven' ekonomicheskogo razvitiya i raspredeleniye ekologicheskoi nagruzki mezhdu regionami RF [Level of economic development and distribution of ecological load between regions of the Russian Federation]. Jurnal Novoi Ekonomicheskoi Assotsiatsii [Journal of New Economic Association], (7), 70-88.

Hamilton, C. (1999). The genuine progress indicator methodological developments and results from Australia. Ecological Economics, 30(1), 13-28.

Klevakina, E. A., \& Zabelina, I. A. (2012). Mezhregional'noye neravenstvo v Rossii: ekologicheskii aspekt [Interregional inequality in Russia: ecological aspect]. Region: Ekonomika i Sotsiologiya [Region: Economics and Sociology], (3), 203-213.

Kubiszewski, I., Costanza, R., Franco, C., Lawn, P., Talberth, J., Jackson, T., \& Aylmer, C. (2013). Beyond GDP: Measuring and achieving global genuine progress. Ecological Economics, 93, 57-68. doi:10.1016/j.ecolecon.2013.04.019.

Manual for Calculating Adjusted Net Savings (2002) Katharine Bolt, Mampite Matete, and Michael Clemens. Environment Department, World Bank.

Pyzhev, A. I. (2015). Otsenka renty v rossiiskom lesnom complexe (po dannym auktsionov) [Forest rent assessment for the Russian economy using timber sale auctions data]. Region: Ekonomika i Sotsiologiya [Region: Economics and Sociology], (1), 147-162.

Pyzhev, A. I., Pyzheva, Yu. I., \& Zander, E. V. (2014). Estimates of the Genuine Progress Indicator of Krasnoyarsk Krai. Journal of Siberian Federal University. Humanities \& Social Sciences, 7(10), 1630-1637. 
Pyzhev A. I., Pyzheva Yu. I. (2015). Otsenka regionalnogo socio-ekologo-ekonomicheskogo blagopoluchiya Krasnoyarskogo kraya: Novy podhod [Evaluation of Regional Ecological and SocioEconomic Well-Being of the Krasnoyarsk Krai: a New Approach]. Regional Economics: Theory and Practice, (34), 30-40.

Ryumina, E. V. Ekonomicheskii analiz uscherba ot ekologicheskih narushenii [Economics analysis of environmental damage]. Moscow, Nauka, 2009.

Zabelina, I. A., \& Klevakina, E. A. (2011). Otsenka ekologitcheskikh zatrat v proizvdednnom valovom regional'nom produkte [The assessment of ecological costs in produced gross regional product]. Region: Ekonomika i Sotsiologiya [Region: Economics and Sociology], (2), 223-232.

Zander, E. V., Pyzhev, A. I., \& Startseva, Yu. I. (2010a). Otsenka ustoichivosti razvitiya ekologoekonomicheskoi sistemy regiona pri pomoschi indikatora "Istinnykh sberezhenii" (na primere Krasnoyarskogo kraia) [The assessment of development sustainability of ecological and economic system of region using the indicator "Genuine Savings" (by the example of Krasnoyarsk Krai)]. Ekonomika Prirodopol'zovaniya [Nature-use Economics], (2), 6-17.

Zander, E. V., Startseva, Yu. I., \& Pyzhev, A. I. (2010a). Green GRP as a Macroeconomic Indicator of Economics Growth of a Region. Journal of Siberian Federal University. Humanities \& Social Sciences, 3(3), 382-387.

\title{
Устойчивое развитие Красноярского края:
}

\section{новые оценки}

\author{
А.И. Пыжев, Е.А. Сырцова, \\ Ю.И. Пыжева, Е.В. Зандер \\ Сибирский федеральнылй университет \\ Россия, 660041, Красноярск, пр. Свободный, 79
}

\begin{abstract}
В статье даются новые оценки индикаторов Истинные сбережения и «Зеленый» ВРП для Красноярского края в 2013 году. Рассмотрены все основные виды природных ресурсов, подвергающихся промышленному освоению на территории региона, а также ключевые разновидности парниковых газов, выбрасываемых в атмосферу. Результаты расчетов подтвердили сохранение антиустойчивых тенденций развития Красноярского края, которые наблюдались начиная с прошлого исследования в 2000-х гг. Динамика Истинных сбережений в иелом совпадает с динамикой Истинного показателя прогресса с точностью до включения в рассмотрение соииальных факторов.
\end{abstract}

Ключевые слова: устойчивое развитие, Истинные сбережения, экологически скорректированный ВРП, Истинный показатель прогресса, региональная экономика.

Исследование выполнено при финансовой поддержке РГНФ и КГАУ «Красноярский краевой фонд поддержки научной и научно-технической деятельности» в рамках научного проекта № 14-12-24003 «Комплексное исследование устойчивости развития соиио-экологоэкономической системы Красноярского края».

Научная специальность: 08.00.00 - экономические науки. 